\title{
SOME VIEWS ON CHRONOSTRATIGRAPHIC CLASSIFICATION
}

SIR,-Some critics of the work of the International Subcommission on Stratigraphic Classification have failed to recognize its emphasis on type-boundaries of chronostratigraphic units-boundaries drawn in the rock strata and commonly known as boundary-stratotypes. These boundaries fix the most essential features of the unit-its time-scope, and its relation to adjacent units. The stratotype of the unit as a whole is the total body of strata formed during the time-span defined by the difference in age of its upper and lower boundaries, regardless of whether or not these are both drawn in the same section, the same area, or even the same region.

Protracted controversies in print may entertain some of the participants but they are headaches for editors and frequently bore the general reader. Many such might be avoided if critics would first discuss their criticisms with the original author privately, and go to print only when they are sure there is a valid difference of opinion or a new thought to be stated. However, the publishing of critical comments without allowing opportunity for the correction of misconceptions, leaves the original author little choice but to make a public rebuttal, or leave the impression by his silence that he accepts the criticism as valid.

During the last two years, a number of British publications have commented on the reports of the International Subcommission on Stratigraphic Classification (I.S.S.C.). Some of these criticisms were discussed by the writer in a commentary entitled "Chronostratigraphy and Biostratigraphy", published in the Geological Magazine in 1965 (after distributing copies to all authors mentioned, before submitting the paper for publication). Subsequently, still further critical letters and comments have appeared, with no effort on the part of the critic or the publisher to bring them to our attention before publication. Since I do not agree with these criticisms, since I believe many of them are due merely to misunderstandings, and since I think it is very important to the progress of international stratigraphy that everyone arrive at a proper general understanding of these points at issue, I believe that publication of the present response is necessary. Needless to say, there are many good points in all of the papers considered, but in order to save space I have commented here in large part only on the points which I think need clarifying or correcting.

T. Neville George (1965) reviewed the discussions in Kashmir of stratigraphic principles and the report of the International Subcommission on Stratigraphic Classification (1964) on "Definition of Geologic Systems". This is a good discussion, although it is not always clear to the reader when Professor George is expressing his own views and when he is merely reporting views expressed at the Kashmir meeting.

Professor George's review does, I think unfortunately, suggest to the reader that the Subcommission had advocated that both top and bottom of a System be defined in one continuous type section, and had done so without realizing the difficulties involved in finding a suitable section of this sort. It is, therefore, well to note that what the Subcommission said in its report (I.S.S.C., 1964, p. 17) was: "In theory, the standard of reference for a System ... should also be a designated stratotype, consisting desirably of a single complete and continuously exposed section of favourable facies for correlation.... However, such single sections representing the strata of an entire Period are rare or non-existent." The Subcommission report then went on to explain that in practice the stratotype of a System might commonly be a composite of the stratotypes of its component stages, and that it was actually the upper and lower boundaries of the System that were of critical importance, anyway.

Professor George says that in order "to make the scheme a little more amenable to rocks as they are " it is necessary to go into the relations between Systems and Stages. This is, of course, exactly what the Subcommission attempted to do (I.S.S.C., 1964, pp. 17-18).

Professor George's concern about " the uppermost beds of the system beneath and the basal beds of the system above " being rarely well represented in the type section of a System seems to have missed the point of the Subcommission's emphasis on boundary-stratotypes " as the really essential features in the definition of chronostrati- 
graphic units since they automatically define the units themselves" (I.S.S.C., 1964, p. 18), regardless of the representation of beds above or below.

Professor George says : "There is some ambiguity in Hedberg's use of stages" because it is stated in the report that Systems might be defined so as to coincide in their upper and lower boundaries with the boundaries of Stages in this same region, while at the same time he finds that the report recognizes " with some uneasiness " the possibility that "local stages distant from System stratotypes will straddle the System boundary or be doubtfully assignable to one or the other System ". I do not think there is any ambiguity involved, and certainly no "uneasiness" on my part regarding this situation. As stated in the I.S.S.C. report $(1964$, p. 17), " many Stages are still primarily regional in usage and it should be recognized that useful Stages may exist provisionally in one region which may not necessarily carry the same name or coincide in time-scope with those of another region." We may desirably strive toward a single set of standard world-wide Stages but at the present time we have many stage divisions which are only regional but are still very useful.

I was startled by the views expressed in the last paragraph of Professor George's review, but again trust these statements do not reflect his own opinion. This paragraph seems to imply that if zones cannot be applied world-wide then there is also little less uncertainty in applying Systems world-wide, and that " there is, in fact, no real expectation of correlating rocks between one country and another". It seems to me that the areal extent over which a chronostratigraphic unit may be identified by time-correlations is directly proportional to its size or rank, and I see no reason why System names such as. Devonian or Cretaceous are not valuable world-wide, even though some other smaller chronostratigraphic units which are useful locally may not be identifiable over the whole world.

J. H. Callomon (1965) would make "standard zones" the only "typologically defined "members of the chronostratigraphic hierarchy. He would also, like Ager (1963), define only the base of each unit. He says that "a standard zone is then based on a type section in which specified beds yield characteristic fauna. The base of the lowest bed yielding this fauna is defined as the base of the zone. The top of the zone is not explicitly defined : the zone extends upwards from the base until either it meets the base of the next standard zone, if defined in the same type section ; or it meets beds containing a fauna characteristic of another standard zone (or it meets an unconformity indicating a marked non-sequence ; or the section ends)".

Unfortunately, Professor Callomon does not define his "standard zone" other than to say that it is based on a type section in which specified beds yield characteristic fauna. Thus we do not know if he is speaking of a biostratigraphic zone (in which case the characteristic fauna would have to be present everywhere that the zone was identified), or of a chronostratigraphic zone (in which case all beds of the same age as the type section would belong to the zone regardless of whether or not they carried the characteristic fauna). However, it would appear from his definition in a previous publication (Callomon, 1964, p. 270) that Professor Callomon's zone would require the presence of certain bio-elements and hence would be a biostratigraphic zone.

J. H. Callomon \& D. T. Donovan (1966) admit that there is a theoretical distinction between biostratigraphic and chronostratigraphic units but this, they say, is unimportant, since chronostratigraphic boundaries can be recognized only by their relation to biostratigraphic boundaries. Even if this latter statement were true, they would seem to have missed the point that the boundaries of no one biostratigraphic zone persist as isochronous horizons, or even approximately isochronous horizons, all around the world through all different facies of rock strata, and that hence individual zone boundaries cannot be true chronostratigraphic boundaries (Hedberg, 1965, Fig. 1, p. 459). Worldwide palaeontological time-correlation through all kinds of rocks formed in all kinds of environments can be carried out only by means of numerous different biostratigraphic zones and markers, laterally replacing each other as facies change. The boundaries of any one biostratigraphic zone inevitably depart from isochronous surfaces, and the distinction between a biostratigraphic zone and its boundaries and a chronostratigraphic zone and its boundaries is, indeed, highly important. 
I am afraid that, in spite of the assertion of Professors Callomon and Donovan to the contrary, most authors at the 1962 Luxembourg Colloquium on the Jurassic did define Stages in terms of biostratigraphic zones rather than chronostratigraphic zones, since they seem to have required the presence of certain bio-elements for identification of the zone rather than merely supposed identity of age. However, I do not doubt that many thought they were dealing with chronostratigraphic zones. My opinion, incidentally, is confirmed by one of the few papers in this colloquium which shows acquaintance with the report of the I.S.S.C., that of P. C. Sylvester-Bradley (1964, p. 259), which says : "A Stage is defined as a Chronostratigraphic Unit, whereas a Zone (in the sense in which we use the term in the Jurassic) is a Biostratigraphic Unit." Likewise, Professor Callomon himself $(1964$, p. 270$)$ in a paper presented to the Colloquium, states that one of the minimum requirements of a zone is "a faunal ammonite assemblage", thus indicating that his zone is fundamentally biostratigraphic.

It is unfortunate that the Jurassic Colloquium did not pay greater attention to the excellent statement transmitted to them by N. F. Hughes of Cambridge (1964, p. 30) which is well worth quoting here verbatim :-

"Stages are definitely chronostratigraphic units (Hedberg, 1961), and although nomenclature should be stabilized as far as possible, the only important characteristic of Stages are the upper and lower boundaries which must ultimately be agreed and fixed by ' a golden spike', in the most appropriate continuous section in the world as a whole. Search for agreement on such sections should be the main purpose now, and naturally the stage boundaries which are also system boundaries should be 'fixed' first. These 'appropriate continuous sections' will only occasionally (if ever) be in the original type (named) area. In the foreseeable future, dating will be with reference to absolute time figures, although it seems probable that Stages will remain as a convenience even after their boundaries have been satisfactorily dated."

Professors Callomon and Donovan apparently support the idea of designating the base only of a chronostratigraphic unit in a type section, not its top; because, they think, it is unrealistic to say that units should only be defined in a section where deposition has been continuous, and because if the boundary should have been drawn at a hiatus, and if missing strata are later discovered elsewhere at the position of this hiatus, these strata can without argument automatically be assigned to the underlying unit whose top has not been defined rather than to the overlying unit whose base has already been defined. Here I think they fail to realize fully the reason for the emphasis in the I.S.S.C. report on type boundaries rather than type full-sections. Granted that hiatuses and diastems are common in many sections, still surely even so it is possible to pick a point for a boundary-stratotype which will lie in an interval of essentially continuous deposition, even if the point has to be placed in the middle of an individual bed in order to make sure. If reasonable care is given to the selection of such a point and sharp breaks in lithology or faunal content are avoided, I think there is little danger of any appreciable gap coinciding with the boundary. While I see no great objection to having so-called " topless" stages, series and systems, this seems to be a rather unnecessary artifice which is only likely to add to confusion. I would much prefer to use care and judgment in the designation of a boundary-stratotype and let it represent at the same time the base of one unit and the top of the next underlying unit.

J. M. Hancock (1966) feels that my paper on "Chronostratigraphy and Biostratigraphy" "has an air of theory divorced from practical application". He says that I object to a time-scale based on " biozones " but have nothing better to offer in its place. I am afraid this is again simply a misunderstanding of my views. I object to saying that a biostratigraphic unit is the same as a chronostratigraphic unit-because it just isn't. "A biostratigraphic unit (a unit representing the actual extent of known occurrence in the rocks of specimens of certain taxons or of certain palaeontological features) rarely, if ever, constitutes a chronostratigraphic unit (a unit representing all rocks formed during a certain time-span of earth history, and only that time-span) (Hedberg, 1965, p. 453). I do not know of any biostratigraphic zone which in itself everywhere fulfills the requirement of a chronostratigraphic zone and hence I cannot go along with the idea of building a time scale out of biostratigraphic zones. On the other hand, this in no way impedes the fullest use of "biozones" and biostratigraphic 
evidence as aids to the building of a chronostratigraphic scale based on chronozones and Stages. I would certainly, of course, support the using of evidence from all kinds of biostratigraphic zones for the recognition and tracing of chronostratigraphic zones. I would gladly use not only these biostratigraphic zones, and all other biostratigraphic evidence, but also all other kinds of evidence for all it was worth. If we are trying to divide the earth's sequence of rocks into units representing equal age everywhere we need all the means of age determination we can find and, in the Phanerozoic particularly, all the evidence from all kinds of fossils, not just the range of occurrences of some one fossil or some one group of fossils, which cannot possibly in itself constitute a body of rocks of equal age everywhere since no fossil or group of fossils were preserved everywhere in all facies of rocks over the whole earth. Let us not continue to live in a dream world of this sort, no matter how attractive its supposed simplicity, but let us get back to reality.

Professor Hancock also urges fixing the base of a stage and leaving the top open to accommodate possible missing strata which might turn up later. In argument for this procedure he poses the following situation : "For example, between the highest beds in the type Cenomanian at Le Mans, and the lowest beds in the type Turonian near Tours, there is at least one whole ammonite zone. In which stage would Dr. Hedberg place this zone?" I think it is simply a matter of reaching international agreement that some certain point in a section of continuously deposited strata is the type CenomanianTuronian boundary (Cenomanian-Turonian boundary-stratotype) and then using all available evidence to the best of our ability to decide the age relation of Hancock's ammonite zone to this point, and hence its consequent proper Stage assignment. As I have said it is not the type section so much as the type boundary which is of importance in determining to which of two adjacent stages certain beds belong. Surely, we all recognize that in any long section there are likely to be difficultly discernible breaks in sedimentation, but $I$ think it is possible to choose certain points in any such section (if necessary within individual beds) where the probability of essentially continuous sedimentation is reasonably assured, and it is such points which we should use for our typeboundary markers.

Finally, with reference to Professor Hancock's last paragraph, I am sure that there is no question but that most of us indeed want a chronostratigraphical scale which allows utilization of fossils to the maximum extent possible for correlation and age determination. What some of us do not want, however, is a scale which is tied to the conceptually false premise that a fossil zone is a chronostratigraphic unit, instead of only an aid to the identification of a chronostratigraphic unit, and which, by defining its units in terms of fossils rather than in terms of intervals of strata, hinders the use of other methods of correlation and age determination.

D. T. Donovan in his recent book entitled "Stratigraphy, an Introduction to Principles" (1966) recognizes the importance of international agreement on stratigraphic practice. However, although recognizing lithostratigraphic and biostratigraphic units, he opposes the idea of chronostratigraphic units which has been supported by the International Subcommission. He apparently believes that there is no difference between biostratigraphic and chronostratigraphic units and that there should be no attempt to define such units as Stages (which he considers as biostratigraphic) by type sections. (Although he apparently would define the base of a stage in a type section.)

Professor Donovan (1966, p. 157) says that the Subcommission considers zones to be biostratigraphic units whereas it considers stages to be chronostratigraphic. More correctly, however, while the Subcommission does consider Stages to be chronostratigraphic, it recognizes both biostratigraphic zones and chronostratigraphic zones, but insists on the distinction between the two. Professor Donovan objects to chronostratigraphic units because he says their boundaries can only be fixed on biostratigraphic criteria, and hence have no separate existence. He says (p. 158): "The position adopted here, then, is that zone, stage, series and system are all units of the same kind : they are biostratigraphical units, which is merely another way of stating that they are defined by fossils." He presents a figure (Fig. 32) to show relationships between different kinds of stratigraphic units. To me, the most revealing part of this figure is that while his stages are bounded throughout the diagram by isochronous lines, the boundaries of 
his zones, while shown to be isochronous or nearly so in one local area, are stopped short at the edges of this local area-for the simple reason, I would say, that if they were extended farther they could realistically be shown only as departing drastically from isochronous lines as they encountered changes in formations or changes from marine to non-marine facies.

I am pleased to see that Professor Donovan (1966, p. 160) emphasizes that geologic time terms (period, epoch, age, etc.) are dependent for definition on units such as systems, series, stages, etc., and not vice versa.

A review of Professor Donovan's book by "W. B. H." (1966) attempts to categorize existing views on stratigraphic classification into four contrasting points of view. View 1 of these purports to be that of the American Commission and, more specifically, my own view. My only objection to "W. B. H."'s statement is that he says that View 1 seems to miss the fact "that ideal time divisions can be based on standard reference points in specified lithological divisions and that all discussion of time can be referred to the corresponding standard divisions defined in actual rock. The actual rock includes all characters, including biocharacters". This is, of course, exactly what the International Subcommission, the American Commission and I myself have been maintaining for many years, so it is a little disconcerting to hear now that we have missed this fundamental point.

Finally we come to the report of the British Stratigraphical Code Sub-Committee (1967). This is in many respects a useful document. By and large it seems to conform rather closely with principles and rules already set forth (for example, by the American Commission and the International Subcommission), but at the same time it seems to have made a conscious effort to develop some novel variations. The creation of the Standing Stratigraphical Committee and its Sub-Committee on the Stratigraphic Code are welcome steps, and hopefully will lead to fuller co-operation between British geologists and the International Subcommission . A few points, however, seem to require comments.

1. A stated purpose of the British Code is to "be of use internationally", and again " to establish principles and procedures ... and to seek international agreement to the adoption of such principles and procedures", and still again "to establish rules for the definition of marker points . . . and to seek international agreement to the adoption and administration of such rules" (my underlining). One cannot help wonder why, with all the stress on the international role of this code, no attempt was made to co-operate with the International Subcommission on Stratigraphic Classification of the International Commission on Stratigraphy.

In May, 1965, when the British Standing Stratigraphical Committee was first formed, it was invited to become an organizational member of the International Subcommission and it officially accepted this invitation. Accordingly it was supplied with the publications and recent circulars of the Subcommission and invited to participate in the work of the Subcommission. Nevertheless, the British Code Sub-Committee made no attempt to officially consult with the International Subcommission about its proposed Code previous to the appearance of this Code full-blown in March, 1967.

2. The proposal to define only the lower limit of each division of the Standard Scale (p. 76, 2D) is indeed novel among codes although, as mentioned above, it has been suggested in a number of recent British papers. Personally, I see little point in this procedure since it seems to me that in a continuously deposited sequence of beds the base of one unit of the standard scale must automatically be the top of the underlying unit, and it would seem to me a relatively simple task to make sure that the boundary between two units was drawn in a section representing essentially continuous deposition. I am glad to see that on page 81 (B, iii), it is agreed that "the top of each division should be defined by reference to the base of the next succeeding division ".

3. It is stated (p. 77, 3A) that " a major purpose of this report is to urge the desirability of setting up an objective standard and making it universally applicable ". This has, of course, been the stated purpose of the International Subcommission and one of the goals of its efforts for the last 15 years ! 
4. The British Code (p. 78, 3G) states that "the 'Copenhagen Principles' (International Subcommission, 1961), although recognizing the need for a scheme of 'standard named chronostratigraphic units', do not explicitly advocate the one requisite for the attainment of international uniformity, namely, the establishment and adoption of a stratigraphical reference-scale covering the whole of geological time, of which the divisions are standardized by reference to marker points in type sections"! Uninformed readers of this amazing statement could only interpret it to mean that the International Subcommission had failed to recognize the need for a standard stratigraphic scale and the need for units of this scale to be based on specifically defined limits, and that consequently the British Sub-Committee had found it necessary to come to the rescue. This unfortunate misrepresentation of the International Subcommission's statement has no doubt served to impress that part of the British geological public unfamiliar with the work of the I.S.C.S. with the great need for the report of the British Sub-Committee in the interests of world stratigraphy. However, members of the International Subcommission all over the world must be either greatly amused or somewhat irritated, depending on their temperaments, by this statement, in view of the following quotations which can be cited from the so-called "Copenhagen Principles" (I.S.S.C., 1961).

(a) (p. 28, D8). "A goal of chronostratigraphic classification is the establishment of a complete and systematically arranged hierarchical sequence of named and defined chronostratigraphic units . . . which can be accepted generally as a standard scale of reference for the dating of all rocks and the relating of all rocks to geologic history."

(b) (p. 29, D8). "It would be desirable . . that we might have a single and uniform standard sequence of consecutive but mutually exclusive units to which geological events and geochronology.could be related."

(c) (p. 24, D3). "A stage should be based on a specifically designated and delimited type section or reference sections. Its designated boundaries in the type section...."

(d) (p. 25, D4). "A substage, like a stage, should be based on specifically designated and delimited type or reference sections."

(e) (p. 25. D5). "The specific interval of geologic time which the rocks of any series represent is defined by the time-scope of a type sequence of strata for that series. ... The basis for definition of a series should be a specifically designated and delimited type or reference sequence of strata."

$(f)$ (p. 27, D6). "The basis for definition of a system should be a specifically designated and delimited type or reference sequence of strata."

(g) (p. 12,9). "For a chronostratigraphic unit to have adequate significance, the time interval which it represents must be based on a specifically designated type or standard reference section of rock strata."

Similar stressing of the importance of designated boundary-stratotypes for the divisions of the standard stratigraphic reference scale is contained in the I.S.S.C. Report on Definition of Geologic Systems (I.S.S.C., 1964). In fact, even the original request to the International Geological Congress in 1952 for the setting up of the I.S.S.C. (Hedberg, 1954) stressed that " the upper and lower limits of all time-stratigraphic units should be specifically defined, both geographically and as regards position in the rock succession, in some type section or type area, in order to provide a standard control for the unit ". Hence, it is no wonder that the published statement of the British Code Sub-Committee is somewhat startling. What difference is there between " divisions which are standardized by reference to marker points in type sections" and units whose boundaries are designated and delimited in type sections?

5. The statement is made (p. 79, L) that " existing concepts of "time-stratigraphic units ' as notionally perfect entities approachable asymptotically by progressive refinement in correlation, must be replaced by the acceptance of physically accessible markerpoints which constitute the ultimate authority". I trust that this statement does not refer to the extending of a unit away from its stratotype or the extending of a boundary away from its stratotype since the concept of the unit, as the strata formed during the time interval spanned between its base and its top, is indeed "notionally perfect", and location of boundaries away from the stratotype is indeed approached " asymptotically by progressive refinement in correlation ", not by the establishment of arbitrary marker points away from the type section. 
6. The British code introduces the terms : chronomere (time unit) and stratomere (stratigraphic unit). I see no objection to these terms, if they help anyone. It should be recognized, however, that formations and assemblage zones, not merely chronostratigraphic units, are by this definition also stratomeres since they are also stratigraphic units.

7. (p. 83). The term "chron" is said to be a new term meaning the smallest standard division of "the Chronomeric Standard Scale" and corresponding to a Standard Chronozone. However, it is really not new. H. S. Williams (1901) used it as "an indefinite division of geologic time" and it was also used in my paper presented to the E.C.A.F.E. meeting in Tokyo in 1965 as the time period corresponding to a chronozone. (See also Hedberg, 1967, Fig. 1.)

8. (p. 83) The expression "Stratomeric Standard Scale" appears undesirable since, according to the definition given, any kind of stratigraphic unit is a stratomere whereas the "Stratomeric Standard Scale" apparently corresponds only to what has been referred to as the "standard chronostratigraphic scale" by I.S.S.C. (1961, p. 29). Incidentally, it is interesting that the British code nowhere appears to recognize the category of chronostratigraphic units. Why not?

9. The suggestion that the fossil name of a "standard chronozone" be printed in different type to differentiate it from a biostratigraphic zone seems unnecessary since there is no danger of confusion of a chronostratigraphic zone with a biostratigraphic zone as long as the former is termed a chronozone.

10. (p. 85). The terms " Total-range Zone ", " Local-range-Zone ", " Partial-rangeZone " and "Consecutive-range-Zone" appear to be an unnecessary complication of verbiage. The range of a fossil is its range and its range-zone is its range-zone and nothing else. The term "local-range-Zone" is meaningful only if you specify the geographical locality or area, and if you do that you don't need the adjective "local". As for " partial" and "consecutive" range zones, from the definitions given, it is certainly not clear to me what these are.

11. It seems to me that the British code is a commendable attempt at trying to come out with something new and different but that it is too bad that it has not presented in draft to the International Subcommission for comments and suggestions before publication. This would have been a step toward international uniformity rather than toward increased divergence.

In conclusion, it seems to me that much of the confusion and difficulty surrounding the definition of stages and other chronostratigraphic units could be avoided if it were adequately recognized that for any chronostratigraphic unit it is really only the boundaries in the rock strata which it is important to define locally by stratotypes, since it is these alone which fix the essential features of the unit-its time-scope in the rocks and its relations to adjacent units. Moreover, there is no need for the types of the upper and the lower boundaries both to be drawn in the same area or even in the same region.

The concept of the nature of a chronostratigraphic unit (its lithology, fossils and other characters of the rock formed during this time-span) is, of course, also very important, but can be obtained not from any local type section (which will represent merely a particular local facies of the whole), but only from a study of the entire body of rocks formed over the whole world during this particular time-interval. The stratotype of a chronostratigraphic unit is thus really the total body of strata between the boundarystratotype separating it from the next overlying stage and the boundary-stratotype separating it from the next underlying stage, even though these boundary-stratotypes might have been designated in quite different areas or regions. And the important task of chronostratigraphy is to agree on the position of boundary stratotypes (Hedberg, 1954, p. 220 ; Hughes, 1964, p. 30 ; I.S.S.C., 1961, pp. 24-7 ; I.S.S.C., 1964, p. 18).

\section{REFERENCES}

AGER, D. V. 1963. Jurassic Stages. Nature, Lond., 198 (4885), 1045-6.

Callomon, J. H. 1964. Notes on the Callovian and Oxfordian stages. Colloque $d u$ Jurassique à Luxembourg, 1962, 269-291. Imprimerie St-Paul, S.A., Luxembourg. 
Callomon, J. H. 1965. Notes on Jurassic stratigraphical nomenclature : 1. Principles of stratigraphic nomenclature. Carpatho-Balkan Geological Association, VII Congress. Sofia, September, 1965. Reports, Part II, 1, 81-5.

\& Donovan, D. T. 1966. Stratigraphic classification and terminology. Geol. Mag., 103 (1), 97-9.

Donovan, D. T. 1966. Stratigraphy-an introduction to principles. Thomas Murby \& Co., London, $199 \mathrm{pp}$.

George, T. Neville. 1965. Stratigraphical systems : Report on discussion in Kashmir. Proc. geol. Soc. Lond., No. 1624, 109-113.

Hancock, J. M. 1966. Theoretical and real stratigraphy. Geol. Mag., 103 (2), p. 179.

HedberG, H. D. 1967. Status of Stratigraphic Classification and Terminology. IUGS Geological Newsletter, No. 3, 1st Sept., 1967, 16-29. Antwerp.

1965. Chronostratigraphy and biostratigraphy. Geol. Mag., 102 (5), 451-461.

Hughes, N. F. 1964. Stages and boundaries in stratigraphy. Colloque du Jurassic à Luxembourg, 1962, p. 30. Imprimerie St-Paul, S.A., Luxembourg.

I.S.S.C. 1961. Statement of principles of stratigraphic classification and terminology (with accompanying glossary of terms). 21st Int. Geol. Cong., Rep. Part 25, $38 \mathrm{pp}$., Copenhagen.

1964. Definition of Geologic Systems. 22nd Int. Geol. Cong. Rep. Part 18, 26 pp., New Delhi. (See also Bull. Am. Ass. Petrol. Geol., 49 (10), 1694-1703, 1965.

Stratigraphical Code Sub-Committee (Geological Society of London), 1967, The stratigraphical code. Proc. geol. Soc. Lond., No. 1638, 75-87.

Sylvester-Bradiey, P. C. 1964. Type sections of Bathonian, Portlandian, and Purbeckian stages, and the problem of the Jurassic-Cretaceous boundary. Colloque du Jurassique à Luxembourg, 1962, 259-263. Imprimerie St-Paul, S.A. Luxembourg.

"W. B. H." 1967. Review of "Stratigraphy. An introduction to principles". Geol. Mag., 104 (2), 192-4.

Williams, H. S. 1901. The discrimination of time-values in geology. J. Geol., 9, $570-585$.

DePartMent OF GEOLOGY,

Hollis D. HedBerg.

PRINCETON UNIVERSITY,

NEW JERSEY 08540.

lst February, 1968.

Editors' Note.-The Editors publish this letter in full because of the international standing of the author, who has long presided in this field. Publication has not been delayed to secure in this issue replies to the points made, for in this field there seems to be some urgency to seek understanding and clarification-and these pages are available for this purpose. However, the Editors will not accept further correspondence primarily concerned to justify or indicate a position already stated, but rather to advance understanding of a matter that does not seem to have been adequately expressed as yet. 